\title{
Creative Drama in Science Education: The Effects on Situational Interest, Career Interest, and Science-Related Attitudes of Science Majors and Non-Science Majors
}

\author{
Kiah-Ju Ong ${ }^{1,2^{*}}$, Ying-Chyi Chou ${ }^{1}$, Ding-Yah Yang ${ }^{1}$, Chi-Chau Lin ${ }^{1}$ \\ 1 Tunghai University, TAIWAN \\ 2 Universiti Tunku Abdul Rahman, MALAYSIA
}

Received 5 October 2019 - Revised 10 December 2019 - Accepted 13 December 2019

\begin{abstract}
This research investigated the effects of creative drama on situational interest, career interest, and science-related attitudes of science majors and non-science majors. Also investigated were students' perception toward creative drama. 55 science majors and 28 non-science majors from five high schools in Malaysia voluntarily participated in this 5-day creative drama activity held in Taiwan. They completed pre-tests on "The Individual Interest Questionnaire" and "Test of Science-Related Attitudes". They designed, prepared, and presented their creative drama during the 5 -day. A post-test was administered after the activity. Creative drama was found to have triggered the situational interest in science within both majors. The career interest and sciencerelated attitudes of science majors were found to have significant improvement; some students' perception toward science careers and science have changed after the activity. Some students commented that creative drama had developed their courage, social skills, teamwork, creativity, self-reflection, presentation skills, critical thinking, and problem-solving skills.
\end{abstract}

Keywords: career interest, creative drama, science-related attitudes, science education, situational interest

\section{INTRODUCTION}

Industry 4.0, which is characterized by the integration of technologies between the biological, physical and digital spheres (Schwab, 2016), has been ongoing since the start of twenty-first century. Future workplaces will emphasize more on STEM skills (Deloitte Access Economics, 2014). STEM is the acronym for science, technology, engineering, and Mathematics. In order to sustain the rapid development of the world, people need to equip themselves with scientific literacy, STEM skills, and skills of the twenty-first century (Deloitte Access Economics, 2014; Glynn, Brickman, Armstrong, \& Taasoobshirazi, 2011; Kivunja, 2015).

Interest in science (Ainley, Hidi, \& Berndorff, 2002; DeBacker \& Nelson, 2000) and positive science-related attitudes (Osborne, Simon, \& Collins, 2003; Salta \& Tzougraki, 2004) are promoting the learning of science. It is therefore important to trigger the interest in science learning and promote science-related attitudes among students. The learning of science prepares one with scientific literacy and STEM skills, which have become increasingly important in the twenty-first century. Thus, it is crucial to promote science learning among the students.

Nowadays, many students lose the motivation to learn science, these include both science majors and nonscience majors (Glynn et al., 2011). Non-science majors often have negative attitudes toward science (French \& Russell, 2001). Therefore, approaches such as problem-based learning (Hung, Hwang, \& Huang, 2012), science fairs (Schmidt \& Kelter, 2017), and STEAM education (Choi, Yang, \& Hong, 2016) have been used to promote the learning of science. STEAM is the acronym for science, technology, engineering, arts, and mathematics. Recently, STEAM education has started to gain traction as it promotes the learning of science (Kong, Huh, \& Hwang, 2014)

(C) 2020 by the authors; licensee Modestum Ltd., UK. This article is an open access article distributed under the terms and conditions of the Creative Commons Attribution License (http://creativecommons.org/licenses/by/4.0/). $\square$ ongkiahju@gmail.com ongkj@utar.edu.my (*Correspondence) $\square$ ycchou@thu.edu.tw $\square$ yang@thu.edu.tw 


\section{Contribution of this paper to the literature}

- Creative drama was found to have triggered the situational interest in science within science majors and non-science majors.

- The career interest and science-related attitudes of science majors were found to have significant improvement; some students' perception toward science careers and science have changed after the creative drama activity.

- Some students commented that creative drama had developed their courage, social skills, teamwork, creativity, self-reflection, presentation skills, critical thinking skills, and problem-solving skills.

and equips one with the scientific literacy (Allina, 2017) and skills required for the twenty-first century (Liao, Motter, \& Patton, 2016).

Despite the many efforts to promote science education, the number of students pursuing science-related courses remains on a declining trend (Academy of Science Malaysia, 2018; Wienk, 2017). Research has indicated that interest (Archer et al., 2010; Holmegaard, Madsen, \& Ulriksen, 2012) and attitude (Katz, 2002) are the key factors that influence the learning of science among students.

Sun, Chen, Ennis, Martin, and Shen (2008) indicated that activities that are novel, challenging, fun, and require attention and exploration can trigger the students' situational interest. According to Arieli (2007), creative drama is entertaining, novelty, attention-grabbing, and stimulating multi-sensory and imaginative. It is a holistic learning tool that facilitates learning (Gul \& Gucum, 2015), where students can enjoy learning and deepen their knowledge of abstract scientific concepts (Arieli, 2007). The integration of creative drama into STEM education is a shift towards STEAM (Colucci-Gray et al., 2017). As creative drama and STEAM education both promote interest in science, science learning, and scientific attitudes; hence, in this research, both science majors and non-science majors were exposed to creative drama.

Thus far, it does not seem as though there has been a research on the effects of creative drama on the career interest of science majors and the situational interest, career interest, and science-related attitudes of non-science majors. Therefore, it is imperative to investigate the effects of creative drama on the situational interest, career interest, and science-related attitudes of science majors and non-science majors. It is important too to understand the students' perception toward creative drama.

\section{LITERATURE REVIEW}

\section{STEAM Education}

STEAM is the acronym for science, technology, engineering, arts, and mathematics. Arts include the art of aesthetics and designs, liberal arts, language, music, drama, theatre, and dance (Colucci-Gray et al., 2017). Science and arts are reciprocal as science offers methodological tools for art, while art offers creative models for the development of science (Kim, Kim, Nam, \& Lee, 2012). STEAM is a practical and holistic education framework as it enriches the scope of STEM education (Taylor, 2016).

STEAM generates more creative pedagogies. As such, students have better perceptions and feelings toward STEM subjects (Colucci-Gray et al., 2017). STEAM fosters, engages, and motivates the students in STEM learning (Colucci-Gray et al., 2017). STEAM had significant influences on human development (Trowsdale, 2015). Studies showed that STEAM promotes science learning (Choi et al., 2016), development of emotions (Hardiman, Magsamen, McKhann, \& Eilber, 2009), creativity, cognitive growth, long-term memory (Hardiman et al., 2009; Sousa \& Pilecki, 2013), self-reflection, communication, collaboration, and innovation skills (Naithram, 2014). Students who participated in STEAM activities showed better self-efficacy, scientific attitude, and interest in science (Kong et al., 2014).

\section{Creative Drama}

Creative drama is a form of art as well as a form of drama in education (Özbek, 2014). It is an instructional strategy, art domain, and a cultural pedagogy (Adiguze \& Timucin, 2010). Creative drama is improvisational, nonexhibition, and process-oriented (McCaslin, 2006).

Creative drama is a student-centred learning activity which requires active and dynamic interaction among students (McCaslin, 2006). In creative drama, students do not receive any script, technical aides or coaching by the teacher. They are, however, guided by a leader to explore, reflect upon human experiences, re-enact, and express ideas or concepts (McCaslin, 2006). During the activity, students are asked to research, express ideas and suggestions, and make decisions (McCaslin, 2006). Creative drama integrates one's cognitive and affective 
responses (Peter, 2003) as it delivers knowledge, sparks interest, solves problems, promotes creativity, imagination, deep learning, as well as expands the students' life experiences and knowledge. Creative drama has been found to bring accomplishment and profound impacts on the students (McCaslin, 2006). It arouses curiosity (Ozdemir \& Ustundag, 2007), promotes self-development, social development, and communication skills (Gul \& Gucum, 2015), thus creating an interesting learning experience. The different types of perceptions, processes, and knowledge reinforced and strengthened during the activity (Ashton-Hay, 2005) will ensure that the knowledge is ingrained into long-term memory (Shams \& Seitz, 2008).

Studies on creative drama mainly focused on the effects of creative drama as an instructional strategy for the learning of science (Arieli, 2007; Ceylan, Polat, Akpınar, Ulusal, \& Kalender, 2015; Çokadar \& Y1lmaz, 2010; Hendrix, 2011; Hendrix, Eick, \& Shannon, 2012; Taskin-Can, 2013). Some studies focused on the effects of creative drama on science academic achievement and attitudes (Cokadar \& Y1lmaz, 2010; Dogru, Yilmaz, Kalay, \& Gençosman, 2010; Ozek, 2016; Taskin-Can, 2013, Timothy \& Apata, 2014). The meta-analysis done by Batdi and Batdi (2015) and Sengun and Iskenderoglua (2010) indicated that creative drama has significant positive effects on academic achievement, creativity, critical thinking skills, affective domain, and attitude. Research on drama is widely found within the science education literature, but hardly found in the STEAM education literature. However, drama was evident in STEAM (Colucci-Gray et al., 2017).

Most studies focused on the application of creative drama as an instructional strategy to improve science academic achievement and attitude. Thus far, it does not seem as though there has been a research on the effects of creative drama on the career interest of science majors and the situational interest, career interest, and sciencerelated attitudes of non-science majors. It is therefore, important to conduct studies on these.

\section{Interest}

Interest is a psychological state and a motivational variable (Renninger \& Hidi, 2016). As a psychological state, interest is rooted on one's physiological response. It emerges from the interaction between a person and objects within social and institutional settings (Renninger \& Hidi, 2016). One's attention and positive feeling towards an object will increase when interest is triggered (Hidi, 2006). Meanwhile, interest as a motivational variable is characterized by the re-engagement of the object over a period. Both definitions are reciprocal; the triggered interest needs support to develop into a motivational variable, while the motivational variable needs to trigger regularly to sustain the psychological state (Renninger \& Hidi, 2016).

There are two types of interest: situational interest and individual interest (Renninger, 2000). Situational interest is temporary and situationally bound. It is triggered by structural characteristics or content features (Renninger \& Hidi, 2016). It develops into individual interest when there is constant support and re-engagement to the object over a period (Hidi \& Renninger, 2006; Silvia, 2008). Individual interest is a stable personality characteristic. Knowledge, positive emotion, and personal values are the key elements that promote the development of individual interest (Hidi \& Renninger, 2006). Individual interest is always accompanied by motivation, positive emotion, and a strong engagement with the objects. Interest needs to be regularly prompted or situational interest will likely wither otherwise (Renninger \& Hidi, 2016).

Interest can be measured by facial expressions, neuroscientific evidence, behaviour, self-report, words that describe joy (fun, like, enjoy, excited, interesting), engagement, happiness, satisfaction, knowledge learned, and perception (Ainley \& Hidi, 2014).

When there is interest, students will be engaged in their learning (Crouch, Wisittanawat, \& Renninger, 2013; Hidi, 2006; Hidi \& Renninger, 2006). Interest increases one's attention, persistence, and effort (Ainley et al., 2002). People with an interest in learning will set goals to achieve (Senko \& Harackiewicz, 2002) and good learning strategies (Azevedo, 2013). They tend to have a better learning curve (Krapp, 1999), self-efficacy (Bong, Lee, \& Woo, 2015), and self-regulation (Sansone \& Thoman, 2005).

\section{Career Interest}

Interest influences one's behaviour, goals, motivation, persistence, and adaptability (Rounds \& Su, 2014). Career interest is also known as vocational or occupational interest, that is the perception of likes, dislikes, and indifference towards career-relevant activities (Lent, Brown, \& Hackett, 1994). One's interest may change several times during life, however, the meta-analysis done by Low, Yoon, Roberts, and Rounds (2005) indicated that vocational interest is relatively stable as it continues over time. Hence, it can be used to predict educational and career choices, career performances, and success (Rounds \& Su, 2014).

Su (2012) conducted a national longitudinal study on 400,000 high school students from 1,353 schools across America. The findings showed that interest is a major factor of academic and career success compared to cognitive ability and personality. Students with an interest in their major will show better performance, persistence, and 
retention (Nye, Su, Rounds, \& Drasgow, 2012). Meanwhile, employees with vocational interest will perform and contribute more and tend to be more persistent (Nye et al., 2012).

When Maltese and Tai (2010) interviewed 116 scientists and graduate students from the field of chemistry and physics, $65 \%$ of the interviewees indicated that their involvement in science-related careers was due to their interest in science before middle school.

\section{Science-related Attitudes}

Science-related attitudes can be divided into attitude towards science and scientific attitude. Gardner (1975) defined attitude towards science as one's feeling, belief, and value about a science-related object. Meanwhile, science-related attitudes involve a complex mixture of attitudes such as curiosity, scepticism, open-mindedness and honesty displayed by scientists during work.

The test of science-related attitudes (TOSRA) was developed by Fraser (1981). TOSRA measures seven facets of science-related attitudes. They are social implications of science, normality of scientists, attitude towards scientific inquiry, adoption of scientific attitude, enjoyment of science lessons, leisure interest in science, and career interest in science. There are 70 items (ten items per each facet) in the questionnaire using a five-point Likert scale ranging from 'strongly disagree' to 'strongly agree'.

Studies showed that positive science-related attitudes led to greater interests in science and the selection of science courses (Catsambis, 1995; Weinburgh, 1995). Students with positive attitudes are more focused and have better engagement (Jarvis \& Pell, 2005). They have better learning curve and scientific processing skills (Yager, 1996).

\section{THE PRESENT STUDY}

Arieli (2007) indicated that creative drama is entertaining, a novelty, attention-grabbing, and stimulates multisensory learning and imagination. Research has indicated that activities that are a novelty, challenging, require attention and exploration, and fun can trigger the students' situational interest (Sun et al., 2008). According to Renninger and Hidi (2016), interest can be triggered through drama. Furthermore, the findings of the meta-analysis have indicated that creative drama has significant positive effects on students' attitudes (Batdi \& Batdi, 2015; Sengun \& Iskenderoglua, 2010).

Built on earlier literature, the present study extended the previous research by investigating the effects of creative drama on situational interest, career interest, and science-related attitudes of science majors and nonscience majors. The present study also investigated students' perception toward creative drama. The following research questions were investigated:

1. Does creative drama trigger situational interest in science among science majors and non-science majors?

2. Does creative drama trigger career interest in science among science majors and non-science majors?

3. Did the perception of science majors and non-science majors toward pursuing a science-related career/scientist change after participating in creative drama?

4. Does creative drama influence science-related attitudes of science majors and non-science majors?

5. Does creative drama affect situational interest, career interest, and science-related attitudes of science majors differently from non-science majors?

6. What are the students' perception towards creative drama?

\section{METHOD}

\section{Theoretical Framework for Creative Drama Activity}

Glasson learning cycle (1993) was used as the framework for this research. It is an interactive and spiral instructional model which consists of three phases: exploration, clarification, and elaboration (Figure 1). Glasson learning cycle was found to be suitable for the learning of science as it focuses on student learning and social interaction among the students. It provides a platform for students to explore, clarify, and discuss (Glasson, 1993). Glasson learning cycle fosters the students' collaboration and problem-solving skills (Glasson, 1993). According to Vygotsky theory (1978), knowledge is constructed when students interact with the physical and social environment. In the learning of science, social interaction helps to internalize new or complex understandings, problems, and processes (Glasson, 1993). 


\section{Exploration}

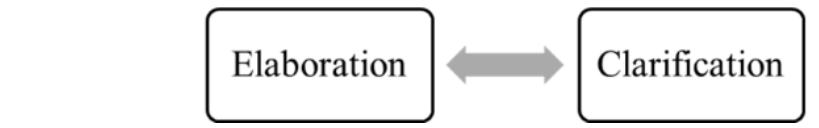

Figure 1. Glasson Learning Cycle (1993)

\section{Participants}

A random sample of 83 high school students (aged 16-18) who voluntarily participated in this activity. The students were from five different high schools in three states (Selangor, Melaka, Johor) in Malaysia. Hence, the findings from the research sample can be used as a generalization of the whole population. In the Malaysian schooling system, students choose their major at the beginning of Form 4 (aged 16-17). Of these, 55 were science majors ( 25 females and 30 males), while the remaining 28 were non-science majors (18 females and 10 males). 82 valid surveys were retrieved (54 science majors and 28 non-science majors) from this study.

\section{Creative Drama Activities}

\section{Science lessons}

In Malaysia, students are taught basic science topics such as living things and non-living things, physical quantities and measurements (energy, light, sound, electricity, and magnet), and the solar system during primary education. Meanwhile, the secondary schooling system is divided into lower secondary (aged 13-15) and upper secondary (aged 16-18) levels. Students are exposed to science subjects (integrated science, which is a merger of physics, chemistry, and biology under general topics) during the lower secondary level. They then choose their major (science or non-science) at the beginning of their upper secondary levels. Science majors learn science as separate subjects (biology, chemistry, and physics). Non-science majors study science subjects as well but as integrated science. Generally, science majors have a better understanding and deeper knowledge of science as they learn science as separate subjects.

Considering that there were differences in the level of understanding of fundamental science concepts and maturity (aged 16-18) of the students, hence, this study did not use specific modules to teach the lessons. Rather, five science lessons with general topics: Application of Physics in the Daily Life (physics), Introduction to Programming (information technology), Concept of Food and Nutrition (biology), Made in Smart factory through Internet and Industrial Engineering (engineering), and Application of Chemistry in the Daily Life (chemistry) were arranged for the students. Each lesson was conducted for 2.5 hours. The students learned about science through these lessons.

\section{Science fiction movie clips workshop}

A few science fiction movies: Interstellar, Lucy, Spiderman, War for the Planet of the Apes, Geostorm, Rampage, Jurassic Park, and Gravity containing physics, chemistry, biology, and technological elements were edited into short movie clips. The students watched the movie clips during the 2-hour workshop to get ideas on how to integrate science into their creative drama.

\section{Presentation skills workshop}

The students learned how to share scientific ideas and knowledge through the proper use of voice, pitch, tone, eye contact, body language, and facial expressions during this 2-hour workshop. 
Table 1. Activities carried out on each day during creative drama activity

\begin{tabular}{ll}
\hline Day & Activities \\
\hline Day 1 & • Pre-test on "The Individual Interest Questionnaire" and "Test of Science-Related Attitudes" \\
& - Presentation skills workshop \\
& - Science fiction movie clips session \\
& - Science lesson: Application of Physics in the Daily Life (physics) \\
& - Group discussion \\
\hline Day 2 & - Science lesson: Introduction to Programming (information technology) \\
& - Science lesson: Concept of Food and Nutrition (biology) \\
& - Group discussion \\
\hline Day 3 & - Science lesson: Made in Smart factory through Internet and Industrial Engineering (engineering) \\
& - Group discussion \\
\hline Day 4 & - Science lesson: Application of Chemistry in the Daily Life (chemistry) \\
& - Group discussion \\
\hline Day 5 & • Group discussion \\
& - Rehearsal \\
& - Presentation (closing ceremony) \\
& Post-test on "The Individual Interest Questionnaire", "Test of Science-Related Attitudes" and open-ended questions \\
\hline
\end{tabular}

\section{Implementation of Creative Drama Activity}

The creative drama activity was a 5-day event organized by a university in Taiwan for the students from Malaysia. It was conducted during the students' one-week school break. In this study, a single group pre- and posttest experiment model was applied.

Before the implementation of creative drama, the students took pre-tests: "Individual Interest Questionnaire" and "Test of Science-Related Attitudes". They were then divided into 10 groups, with each group a mix of eight to nine students (five science majors and two to three non-science majors) from different schools. Through the drawing of lots, each group was given a theme (Chemistry, Biology or Physics) based on which they created and designed a creative drama. The groups could swap their themes if there was an agreement among group members. They could integrate other themes (apart from the theme that they were given) into their creative drama as well. The guidelines for the preparation of creative drama is placed in the Appendix.

Although the themes were provided, no fixed titles were given to the students. The students were free to share scientific knowledge and ideas on their topic of interest in their creative drama. The main idea of this research was to trigger the students' situational interest and career interest in science as well as promote science-related attitudes, rather than forcing them to learn a specific science topic. As such, students were given the opportunity to explore their interests, preferences and values by allowing them to work their creative drama with full autonomy. Research has indicated that autonomy support can nurture one's internal locus and volitional intentions to act (Reeve \& Jang, 2006), improves competency, interest, enjoyment, performance (Black \& Deci, 2000), and creativity (Amabile \& Pillemer, 2012).

None of the students had participated in creative drama activities before, hence, a 2-hour presentation skills workshop and a 2-hour science fiction movie clips workshop were arranged for them. The arrangement of activities conducted is shown in Table 1.

The 'exploration' phase of the Glasson learning cycle started with the science lessons. The details of the activities for each phase are shown in Table 2. Every day after the students completed the lesson(s) and learned certain science concepts/knowledge, they were given 4.5 hours for group discussion, which could be extended at their own discretion. During the 'exploration' phase, the students had group discussions and designed creative drama (e.g. the planning of storyline, characters, and dialogue). They did research, discussed ideas, and tried to dramatize science concepts and ideas. While exchanging ideas and manipulating materials, they might experience cognitive disequilibrium. Cognitive disequilibrium will drive the students to investigate as they seek new information to clarify their doubts. During the 'clarification' phase, the students worked actively (e.g. raised questions, developed concept maps, did research) to clarify the meaning of scientific explanations and then constructed new knowledge based on their investigations. From there, the students formulated their creative drama and consequently acted out their drama. Teachers facilitated the group discussion by providing scientific information and explanations, when needed. During the 'elaboration' phase, students had group discussions again to refine their drama to better reflect scientific views. Their science knowledge and understanding deepened further when they engaged in divergent problem-solving. 
Table 2. Activities conducted by teachers/instructors and students during each phase of the Glasson learning cycle

\begin{tabular}{|c|c|c|}
\hline Phase & Teachers/instructors activity & Students activity (During the group discussion) \\
\hline Exploration & $\begin{array}{l}\text { During the science lesson, } \\
\text { - Explore literature about science views } \\
\text {-Provide scientific information. } \\
\text {-Create activities and that can arise the students' curiosity } \\
\text { - Create activities that can help students reflect on and } \\
\text { communicate their ideas about scientific phenomena } \\
\text {-Ask open-ended questions to promote further } \\
\text { understanding and inquiry }\end{array}$ & $\begin{array}{l}\text { - Work in the group, start to design creative drama } \\
\text { (e.g. the planning of storyline, characters, backdrop, } \\
\text { and dialogue) } \\
\text { - Make assumptions, list and explain predictions and } \\
\text { ideas, raise questions, and consider group members' } \\
\text { opinions } \\
\text { - While exchanging ideas and manipulating materials, } \\
\text { the students might experience cognitive } \\
\text { disequilibrium }\end{array}$ \\
\hline & $\begin{array}{l}\text { During the students' group discussion, } \\
\text { - Facilitate the discussion by providing scientific } \\
\text { information, explanations or suggestions when necessary } \\
\text {-Provide motivational experiences } \\
\text { - Help the students to reflect on and share their ideas } \\
\text { about scientific phenomena } \\
\text { - Clarify the science view when needed } \\
\text {-Ask open-ended questions to promote further } \\
\text { understanding and inquiry }\end{array}$ & $\begin{array}{l}\text { - Work actively (e.g. raised questions, developed } \\
\text { concept map) to clarify the meaning of scientific } \\
\text { explanations based on own view } \\
\text { - Investigate to get scientific information and evidence } \\
\text { to clarify the doubts } \\
\text { - Consider, discuss the group members' science views } \\
\text { and evaluate them } \\
\text { - Construct new knowledge based on investigations, } \\
\text { observations, and discussion }\end{array}$ \\
\hline Elaboration & $\begin{array}{l}\text { During the students' group discussion, } \\
\text { - Clarify the science view when needed } \\
\text { • Help in framing and solving advanced problems } \\
\text {-Provide motivational experiences }\end{array}$ & $\begin{array}{l}\text { - Work in the group, discuss problems, find ways to } \\
\text { improve and refine their creative science drama to } \\
\text { better reflect scientific views } \\
\text { - Solve problems using the concept/knowledge } \\
\text { constructed } \\
\text { - Present creative drama to others during the closing } \\
\text { ceremony }\end{array}$ \\
\hline
\end{tabular}

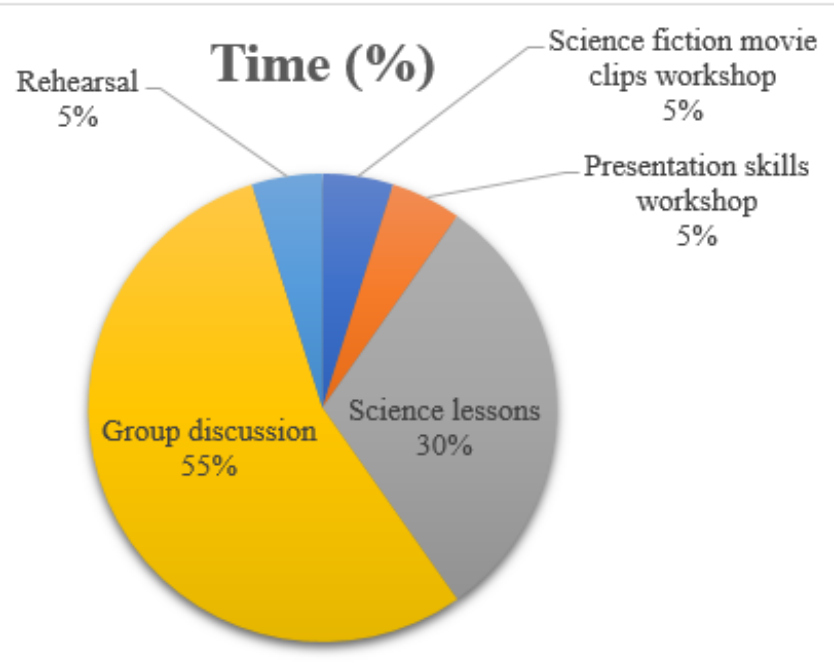

$$
\begin{aligned}
& \text { - Science fiction movie clips workshop } \text { a Presentation skills workshop } \\
& \text { - Science lessons } \quad \text { Group discussion } \\
& \text { - Rehearsal }
\end{aligned}
$$

Figure 2. The time the students spent on each activity during the creative drama activity

The science lessons started the 'exploration' phase of the Glasson learning cycle. However, the student may return to the previously encountered phase at any point of time as the Glasson learning cycle is an interactive and spiral instructional model. The time that the students spend on 'clarification' and 'elaboration' was different based on their group needs, hence, not all the groups were moving through the cycle at the same pace.

A 2-hour rehearsal time was given to the students before their presentation. Figure 2 shows the time the students spent on each activity during the creative drama activity. The students spent about $55 \%$ of their time in group discussions. Some groups spent more than $55 \%$ of the time in group discussions as they were allowed to 
Table 3. Wilcoxon test results for pre-test and post-test of individual interest scores

\begin{tabular}{|c|c|c|c|c|c|c|}
\hline \multirow[t]{2}{*}{ Major } & \multirow[t]{2}{*}{ Pretest -Posttest } & \multirow[t]{2}{*}{$\mathbf{N}$} & \multicolumn{2}{|c|}{ Rank } & \multirow[t]{2}{*}{$\mathbf{z}$} & \multirow[t]{2}{*}{$\mathbf{p}$} \\
\hline & & & Average & Total & & \\
\hline \multirow[t]{3}{*}{ Science } & Negative Ranks & 19 & 16.42 & 312.00 & $-2.333^{\star}$ & .020 \\
\hline & Positive Ranks & 26 & 27.81 & 723.00 & & \\
\hline & Equal & 9 & & & & \\
\hline \multirow[t]{3}{*}{ Non-science } & Negative Ranks & 6 & 9.00 & 54.00 & $-2.756^{\star \star}$ & .006 \\
\hline & Positive Ranks & 18 & 13.67 & 246.00 & & \\
\hline & Equal & 4 & & & & \\
\hline
\end{tabular}

Note. On the basis of negative ranks; ${ }^{*} p \leq 0.05 ;{ }^{* *} p \leq 0.01$

extend the time for group discussion. The movie clip session and the presentation skills workshops only occupied $10 \%$ of their time. The majority of the time was spent on the preparation of creative drama. The students presented their creative drama during the closing ceremony. A post-test, which is identical to the pre-test, along with a few open-ended questions were administered after the end of the activity. According to the literature, situational interest is temporary and situationally bound (Renninger \& Hidi, 2016), hence, the post-test was conducted after the end of the activity.

\section{Research Instruments}

\section{The individual interest questionnaire (IIQ)}

The situational interest of the students was measured by using the individual interest questionnaire (IIQ) (Rotgans, 2015). The IIQ comprises of seven items based on a single factor. It measures one's willingness and tendency to engage a subject, positivity towards the subject, and the willingness to re-engage with the subject over time. Students need to indicate their level of agreement based on a five-point Likert scale from 1 (not true at all) to 5 (very true for me). The Cronbach alpha coefficient was found to be 0.89 .

\section{Test of science-related attitudes (TOSRA)}

The career interest in science and the students' science-related attitudes were measured by using TOSRA (Fraser, 1981). TOSRA measures seven facets of science-related attitude: social implications of science, normality of scientists, attitude towards scientific inquiry, adoption of scientific attitudes, enjoyment of science lessons, leisure interest in science, and career interest in science. Only the latter five facets were adopted in this research. Students need to indicate their level of agreement based on a five-point Likert scale from 1 (strongly disagree) to 5 (strongly agree). The Cronbach alpha coefficient was found to be 0.96 .

\section{Open-ended questions}

The open-ended questions were adopted from Schmidt and Kelter (2017):

1. "Has participating in the [creative drama activity] changed your mind about becoming a scientist [or pursuing a science-related career]? In what way?"

2. "If you could tell me one thing about your [creative drama activity] experience, what would it be?"

\section{Data Analysis}

The data collected were analysed with SPSS 16.0 application. The Wilcoxon signed-rank test was performed as the sample size of the students was small. Quotes from students were translated from Mandarin to English.

\section{RESULTS}

\section{The Individual Interest Questionnaire (IIQ)}

Table 3 illustrates the Wilcoxon test results that of the individual interest scores of both pre- and post-tests. Significant differences were found between the pre- and post-tests' individual interest scores of science majors $(\mathrm{z}=$ $-2.333, p \leq 0.05)$ and non-science majors $(z=-2.756, p \leq 0.01)$ favouring the positive rank. The findings showed that creative drama significantly triggered situational interest in science within science majors and non-science majors. 
Table 4. Wilcoxon test result for pre-test and post-test of career interest in science and TOSRA scores

\begin{tabular}{|c|c|c|c|c|c|c|c|}
\hline \multirow[t]{2}{*}{ Scale } & \multirow[t]{2}{*}{ Major } & \multirow[t]{2}{*}{ Pretest-Posttest } & \multirow[t]{2}{*}{$\mathbf{N}$} & \multicolumn{2}{|c|}{ Rank } & \multirow[t]{2}{*}{$\mathbf{z}$} & \multirow[t]{2}{*}{$\mathbf{p}$} \\
\hline & & & & Average & Total & & \\
\hline \multirow{6}{*}{$\begin{array}{l}\text { Career Interest in } \\
\text { Science }\end{array}$} & Science & Negative Ranks & 17 & 20.65 & 351.00 & $-2.078^{\star}$ & .038 \\
\hline & & Positive Ranks & 29 & 25.17 & 730.00 & & \\
\hline & & Equal & 8 & & & & \\
\hline & Non-science & Negative Ranks & 8 & 13.06 & 104.50 & -1.809 & .071 \\
\hline & & Positive Ranks & 18 & 13.69 & 246.50 & & \\
\hline & & Equal & 2 & & & & \\
\hline \multirow{6}{*}{$\begin{array}{c}\text { Attitude to } \\
\text { Science Inquiry }\end{array}$} & Science & Negative Ranks & 21 & 18.83 & 395.50 & $-2.353^{*}$ & .019 \\
\hline & & Positive Ranks & 29 & 30.33 & 879.50 & & \\
\hline & & Equal & 4 & & & & \\
\hline & Non-science & Negative Ranks & 7 & 11.29 & 79.00 & -1.556 & .120 \\
\hline & & Positive Ranks & 15 & 11.60 & 174.00 & & \\
\hline & & Equal & 6 & & & & \\
\hline \multirow{6}{*}{$\begin{array}{c}\text { Adoption to } \\
\text { Science Attitudes }\end{array}$} & Science & Negative Ranks & 22 & 24.09 & 530.00 & -.116 & .908 \\
\hline & & Positive Ranks & 24 & 22.96 & 551.00 & & \\
\hline & & Equal & 8 & & & & \\
\hline & Non-science & Negative Ranks & 11 & 11.59 & 127.50 & -.648 & .517 \\
\hline & & Positive Ranks & 13 & 13.27 & 172.50 & & \\
\hline & & Equal & 4 & & & & \\
\hline \multirow{6}{*}{$\begin{array}{l}\text { Enjoyment of } \\
\text { Science Lesson }\end{array}$} & Science & Negative Ranks & 16 & 22.41 & 358.50 & -1.391 & .164 \\
\hline & & Positive Ranks & 27 & 21.76 & 587.50 & & \\
\hline & & Equal & 11 & & & & \\
\hline & Non-science & Negative Ranks & 11 & 15.05 & 165.50 & -.569 & .570 \\
\hline & & Positive Ranks & 16 & 13.28 & 212.50 & & \\
\hline & & Equal & 1 & & & & \\
\hline \multirow{6}{*}{$\begin{array}{l}\text { Leisure Interest } \\
\text { in Science }\end{array}$} & Science & Negative Ranks & 18 & 23.61 & 425.00 & -1.872 & .061 \\
\hline & & Positive Ranks & 31 & 25.81 & 800.00 & & \\
\hline & & Equal & 5 & & & & \\
\hline & Non-science & Negative Ranks & 8 & 12.63 & 101.00 & -1.411 & .158 \\
\hline & & Positive Ranks & 16 & 12.44 & 199.00 & & \\
\hline & & Equal & 4 & & & & \\
\hline \multirow[t]{6}{*}{ TOSRA } & Science & Negative Ranks & 23 & 20.98 & 482.50 & $-2.065^{*}$ & .039 \\
\hline & & Positive Ranks & 30 & 31.62 & 948.50 & & \\
\hline & & Equal & 1 & & & & \\
\hline & Non-science & Negative Ranks & 10 & 11.50 & 115.00 & -1.779 & .075 \\
\hline & & Positive Ranks & 17 & 15.47 & 263.00 & & \\
\hline & & Equal & 1 & & & & \\
\hline
\end{tabular}

Note. On the basis of negative ranks; ${ }^{*} p \leq 0.05 ;{ }^{* *} p \leq 0.01$

\section{Career Interest}

The Wilcoxon test results of pre- and post-tests' career interest in science scores are shown in Table 4. A significant difference was noted between the pre- and post-tests scores for science majors $(z=-2.078, p \leq 0.05)$. Meanwhile, the difference between the pre- and post-tests scores of non-science majors was on the borderline of what is deemed as significant $(z=-1.809, p=0.071)$.

\section{Test of Science Related Attitudes}

Table 4 illustrates the Wilcoxon test results of pre- and post-tests' TOSRA scores. A significant difference was noted for the TOSRA scores for science majors $(z=-2.065, p \leq 0.05)$. Meanwhile, the difference between the preand post-tests' TOSRA scores for non-science majors was on the borderline of what is deemed as significant $(\mathrm{z}=$ $1.779, \mathrm{p}=0.075)$. After evaluating the attitude to science inquiry facet, a significant difference was found for science majors $(z=-2.353, p \leq 0.05)$. However, no significant difference was noted for non-science majors $(z=-1.556, p>$ $0.05)$. For adoption to science attitudes scores, significant differences could not be established for the science majors $(z=-0.116, p>0.05)$ and non-science majors $(z=-0.648, p>0.05)$. There was an increased in the pre-test and posttest scores on enjoyment of science lessons for science majors and non-science majors. However, the results revealed that no significant differences were noted for science majors $(z=-1.391, p>0.05)$ and non-science majors $(z=-0.569$, $p>0.05)$. For leisure interest in science, the difference between the pre-test and post-test scores of science majors 
was very close to the established statistical significance level of $p=0.05(z=-1.872, p=0.061)$. No significant difference was noted for non-science majors $(z=-1.411, \mathrm{p}>0.05)$.

\section{Findings of the Open-ended Questions}

\section{"Has participating in the [creative drama activity] changed your mind about becoming a scientist [or pursuing a science-related career]? In what way?"}

18 science majors and four non-science majors stated that creative drama had influenced their desire to become a scientist or pursue a science-related career. Some students commented:

"Yes, I was inspired by the life of some scientists." (science major student)

"Yes, through drama, I knew that it needs a lot of hard work to be a scientist, it is difficult to be a scientist, this has motivated me to work harder to be a successful scientist." (science major student)

"Yes, creative drama made me want to pursue a science-related career. During the rehearsal, I have a better understanding of my interest, I am firm with my decision on pursuing a career related to biology field." (science major student)

"Yes, I was inspired by the live and hard work contributed by Friedrich Wohler, Albert Einstein, Galileo, and Marie Curie." (non-science major student)

"Yes. Science is very interesting, through thinking and experiments, we can invent or discover new things." (non-science major student)

"Yes, I like science after participating in creative drama." (non-science major student)

36 science major students stated that creative drama did not influence their desire to pursue a science-related career, however, 19 of them showed a more positive perception towards science after the activity. Some of them responded:

"No. But creative drama enhances my interest in learning science" (science major student)

"No. However, creative drama has developed my interest in learning science." (science major student)

24 non-science majors stated that creative drama did not influence their desire to pursue a science-related career. Nevertheless, 12 of them showed a more positive perception towards science after the activity. Some of them commented:

"No. Learning science is boring. However, creative drama has changed my impression towards science, I have a little bit of interest in learning science now." (non-science major student)

"No, I am not interested in a science-related career, but I am keen to learn science now." (non-science major student)

"No. Creative drama makes me want to explore and learn more about science." (non-science major student)

A student mentioned that he cannot pursue a science-related career as he is a non-science major student. He remarked:

"No. Although I have an interest in science, however, I cannot be as professional as a scientist. I am a non-science major student, I stopped learning science for such a long time, hence it is impossible for me to become a scientist."

\section{"If you could tell me one thing about your [creative drama activity] experience, what would it be?"}

The comments given by the students were arranged and listed in Table 5. A few students from both majors commented about the same skills. Some of them commented:

"I learned about teamwork spirit through this experience." (science major student)

"I noticed communication skills and interaction are very important, communication promotes cooperation and builds teamwork." (non-science major student)

Some science majors indicated that it was fun to learn science through creative drama as they were able to learn and remember the science knowledge easily. Some of them commented:

"It is fun to learn science through creative drama." (science major student)

"I never know that I can learn science through creative drama." (science major student)

"Creative drama promotes effective learning and I have a deeper impression of the knowledge I learned." (science major student)

Some non-science majors indicated that creative drama allowed them to learn through actions, hence, they can learn and remember the knowledge easily. Some of them commented: 
Table 5. Comments of the students on their creative drama activity experience

\begin{tabular}{ll}
\hline - Creativity & Non-science Majors \\
- Promote critical thinking skills & - Promote self-understanding \\
- Building courage & - Better understanding of science \\
- Stimulating thinking skills & \\
- Providing freedom in discussion & \\
- Learning new science knowledge & \\
- Promote self-reflection \\
- Brainstorming \\
- Teamwork \\
- Making friends \\
- Promote ideas sharing \\
- Promote peers learning \\
- Promote communication/social skills \\
- Learning problem-solving skills \\
- Providing a chance for them to express themselves \\
- Learning science through dramatic form
\end{tabular}

"During the discussion and rehearsal sessions, I learned a lot of scientific knowledge. It is very interesting! Creative drama provides the opportunities for the students who rarely learn science to learn, explore and understand some science concepts and theories." (non-science major student)

"I never knew that a scientific theory can be shattered. For example, Friedrich Wohler shattered the theory of vitalism. Learning science is interesting and the experiments are fun!" (non-science major student)

"Learning science through creative drama can be fun and interesting! I can learn and remember easily. Good!" (nonscience major student)

"Traditional way of learning science is boring. Learning science through creative drama provides more fun, creative drama impressed me and it promotes our imagination." (non-science major student)

\section{DISCUSSION}

Built on earlier literature, the present study extended the previous research by investigating the effects of creative drama on situational interest, career interest, and science-related attitudes of science majors and nonscience majors. This study also investigated the students' perception towards creative drama.

Creative drama significantly triggered situational interest in science within both science and non-science majors. The results are consistent with that reported by other researchers (Arieli, 2007; Batdi \& Batdi, 2015; Choi et al., 2016; Cokadar \& Yilmaz, 2010). Creative drama is a student-centred learning activity. Meanwhile, the Glasson learning cycle provided an appropriate framework for the present study as it offered many opportunities for the students to explore, discuss, and collaborate. These opportunities fostered their autonomy, competence, and confidence which motivated the students. Referring to the self-determination theory (Ryan \& Deci, 2000), a person is motivated when their innate needs were satisfied. As interest is a motivational variable (Renninger \& Hidi, 2016), the students' situational interest was triggered when they were motivated.

No script, technical aides or coaching were provided during the activity, however, guidance from a leader was made available to the students. The students did research, expressed ideas, offered suggestions, and made decisions. Creative drama encouraged active participation and interaction among the students, which triggered the situational interest within the students. In line with the findings by Rotgan and Schmidt (2011), the students' situational interest was triggered during the active learning process.

As no scripts and coaching were provided, therefore, the preparation of creative drama was a novelty, exciting, challenging, complex, and required full attention and exploration, thus arousing the situational interest of the students. These findings correspond with the results of existing studies (Durik \& Harackiewicz, 2007; Sun et al., 2008), where activities with the elements mentioned above can trigger one's situational interest.

During the activity, a creative drama entitled "immune system" was presented. Some students commented that they learned about different types of white blood cells from the presentation. This finding is supported by the findings of Peter (2003), whereby the students were able to grasp the implications immediately if the content of the drama was linked to real-life. The students' situational interest was triggered when they realized the utility value and implication of knowledge. According to Kim, Jiang, and Song (2015), a better comprehension of the utility value and implications can enhance one's situational interest. 
The findings indicated that the career interest in science among science majors had improved significantly. To date, to the best of our knowledge, research on the effects of creative drama on career interest has never been done before. However, literature had indicated that creative drama influences career development (Arveklev, Berg, Wigert, Morrison-Helme, \& Lepp, 2018; Sungurtekin, Sezer, Kahraman, \& Sadioğlu, 2009).

During the activity, several groups presented on the lives of Albert Einstein, Marie and Pierre Curie, Galileo, Friedrich Wohler, Edison, Tesla, and Stephen Hawking. As indicated in the findings, some students were impressed, inspired, and motivated by the lives of these scientists. Generally, students learn about scientific inventions and theories in the classroom; the knowledge acquired is often abstracted and disconnected from the real world. According to situated learning theory, knowledge has to be delivered in an authentic context and learning process requires social interaction and collaboration (Lave \& Wenger, 1991). However, it is sometimes difficult to place the students in a real-life setting such as a laboratory. Creative drama can overcome this problem because it creates an "as-if" world within the classroom. Through the "as-if" world, some essential elements such as the laboratory can be brought to life within the drama sphere. Although they differ from the physical world context, yet, they are sufficient enough to support situated learning and promote learning effectiveness (Anderson, 2004). The "as-if" world allows the students to learn in an authentic context; it provides 'a more authentic sense of work', especially on how scientists work. Through the "as-if" world, students had a better understanding of the life story, hard work, and contributions of these scientists. A better understanding of the content will trigger one's interest (Rotgan \& Schmidt, 2011).

Although there was an improvement in the career interest in science scores for non-science majors, the improvement was insignificant. Non-science majors usually have a lower level of understanding of fundamental science concepts. According to the literature, content knowledge will influence one's learning (Mji \& Makgato, 2006) and self-efficacy (Swackhamer, Koellner, Basile, \& Kimbrough, 2009). Subsequently, self-efficacy influences a person's interest (Bong et al., 2015). Hence, a lower comprehension of science concepts among non-science majors might lead to a lack of career interest in science.

Some students commented that they were initially not interested in pursuing science careers. However, their perception towards science careers and science changed after the activity. These findings are supported by the findings of Cakici and Bayir (2012). Creative drama allowed the participants to role-play in an imaginary environment. The students performed, observed, experienced, and understood science when role-playing. These processes fostered the students' comprehension towards science. In the present study, the change in students' perception towards science careers and science could be due to their better comprehension of science subjects. Research by Fabrigar, Petty, Smith, and Crites (2006) indicated that a deeper understanding of a content will improve a person's attitudes and perceptions.

The findings indicated that science-related attitudes of science majors had improved significantly. These matched the findings of Cokadar and Yilmaz (2010), Dogru et al. (2010), Timothy and Apata (2014) and Kong et al. (2014). The science-related attitudes of non-science majors had improved as well, albeit insignificant. Knowledge content influences one's attitude (Fabrigar et al., 2006), therefore, this could be the reason for the significant improvement in science-related attitudes among science majors and insignificant improvement among non-science majors.

A few students commented that creative drama had developed their courage, social skills, teamwork, creativity, self-reflection, presentation skills, critical thinking, and problem-solving skills. These findings matched the STEAM findings reported by Hardiman et al. (2009), Kong et al. (2014), Naithram (2014), and Sousa and Pilecki (2013). Creative drama is a product of teamwork. It requires active communication, reasoning, cooperation, and collaboration. Although students in the present study were from different backgrounds (age, schools, majors), they had to work as a team to achieve the same goal. During the activity, they learned to share, tolerate, have self-reflect, and accept others' ideas. These processes developed and polished their social skills, teamwork, critical thinking, decision-making, and problem-solving skills.

The findings indicated that the students' creativity, critical thinking, and problem-solving skills were fostered. This is because creative drama was improvisational. Improvisation means spontaneous reaction during a situation (Lehtonen, Kaasinen, Karjalainen-Väkevä, \& Toivanen, 2016). It stimulates the students to analyse problems and synthesize solutions spontaneously. Subsequently, improvisation fosters imagination, creativity, critical thinking, decision-making, and problem-solving skills. The findings also indicated that creative drama developed the students' courage and presentation skills. These findings are in line with Arieli's (2007) who reported that creative drama developed the students' courage and presentation skills.

\section{Implications}

The findings of this research have both practical and theoretical significance. The implications of creative drama in science education are far-reaching and diverse. Educators are encouraged to consider using creative drama as an 
instructional technique and a learning activity to trigger situational interest and career interest in science, promote science-related attitudes, the learning of science, and develop soft skills. The researchers would like to recommend that more elementary school and junior high school teachers use creative drama as a teaching tool. If students' interest in science is triggered earlier, they may choose science as their major during high school. This may eventually lead them to pursue science-related careers.

\section{Limitations and Future Directions}

There were several limitations during this study. Firstly, due to the small sample size, there was no control group. This had restricted the internal validity of the present study (Shadish, Cook, \& Campbell, 2002). Apart from that, the small sample size had constrained the generalization of the findings. In future studies, a control group and a larger number of students should be considered. Secondly, the duration of the activity was constrained as it was conducted during the students' one-week school break. In future, the duration of the activity should be extended and a follow-up on the measurement of interest should be done. Despite the short duration of the activity, the fact that creative drama significantly triggered students' situational interest and career interest in science, had promoted science-related attitudes, and some soft skills is a promising result.

\section{CONCLUSION}

Creative drama significantly triggered the situational interest in science among science and non-science majors. The career interest in science and science-related attitudes of science majors were found to have improved significantly after the activity. The perception towards science careers and science among some science and nonscience majors changed after participating in the creative drama activity. Some students commented that creative drama had developed their courage, social skills, teamwork, creativity, self-reflection, presentation skills, critical thinking skills, and problem-solving skills. Given the promising results, creative drama in science education could be an alternative to promote interest and career interest in science, science-related attitudes, and the development of some soft skills.

\section{ACKNOWLEDGEMENT}

The authors would like to thank greatly appreciate the students, professors, speakers, and teachers who involved in this activity.

\section{REFERENCES}

Academy of Science Malaysia. (2018). Science outlook 2017. Kuala Lumpur, Academy of Sciences Malaysia.

Adiguzel, H. Ö., \& Timucin, E. (2010). The effect of creative drama on student achievement in the instruction of some development and learning theories. Procedia - Social and Behavioral Sciences, 9, 1741-1746. https:// doi.org/10.1016/j.sbspro.2010.12.393

Ainley, M., \& Hidi, S. (2014). Interest and enjoyment. In R. Pekrun \& L. Linnenbrink-Garcia (eds), The International Handbook of Emotions in Education (pp. 205-227). New York, NY: Taylor \& Francis.

Ainley, M., Hidi, S., \& Berndorff, D. (2002). Interest, learning and the psychological processes that mediate their relationship. Journal of Educational Psychology, 94(3), 545-561. https:/ / doi.org/10.1037/ / 0022-0663.94.3.545

Allina, B. (2017). The development of STEAM educational policy to promote student creativity and social empowerment. Arts Education Policy Review, 119(2), 77-87. https:/ / doi.org/10.1080/10632913.2017.1296392

Amabile, T. M., \& Pillemer, J. (2012). Perspectives on the Social Psychology of Creativity. Journal of Creative Behavior, 46(1), 3-15. https://doi.org/10.1002/jocb.001

Andersen, C. (2004). Learning in "as-if" worlds: Cognition in drama in education. Theory into Practice, 43(4), 281286. https://doi.org/10.1207/s15430421tip4304_6

Archer, L., DeWitt, J., Osborne, J., Dillon, J., Willis, B., \& Wong, B. (2010). “Doing” science versus “being” a scientist: Examining 10/11-year-old schoolchildren's constructions of science through the lens of identity. Science Education, 94(4), 617-639. https:/ / doi.org/10.1002/sce.20399

Arieli, B. (2007). The integration of creative drama into science teaching. Ph.D. dissertation, Kansas State University, United States-Kansas. From dissertations \& theses: A \& 1. (Publication No. AAT 3291364).

Arveklev, S. H., Berg, L., Wigert, H., Morrison-Helme, M., \& Lepp, M. (2018). Nursing students experiences of learning about nursing through drama. Nurse Education in Practice, 28, 60-65. https://doi.org/10.1016/j.nepr.2017.09.007 
Ashton-Hay, S. (2005). Drama: Engaging all learning styles. Paper presented in Proceedings 9th International INGED (Turkish English Education Association) Conference, Economics and Technical University, Ankara Turkey, 20-22 October 2005. Retrieved from https:/ / eprints.qut.edu.au/12261/1/12261a.pdf

Azevedo, F. S. (2013). The tailored practice of hobbies and its implication for the design of interest-based learning environments. The Journal of the Learning Sciences, 22(3), 462-510. https:/ / doi.org/10.1080/10508406.2012.730082

Batdi, V., \& Batdi, H. (2015). Effect of creative drama on academic achievement: A meta-analytic and thematic analysis. Educational Sciences: Theory \& Practice, 15(6), 1459-1470.

Black, A. E., \& Deci, E. L. (2000). The effects of instructors' autonomy support and students' autonomous motivation on learning organic chemistry: A self-determination theory perspective. Science Education, 84(6), 740-756. https:/ / doi.org/10.1002/1098-237x(200011)84:6<740::aid-sce4>3.0.co;2-3

Bong, M., Lee S. K., \& Woo, Y. K. (2015). The role of interest and self-efficacy in pursuing mathematics and science. In K. A. Renninger, M. Nieswandt, \& S. Hidi (Eds), Interest in Mathematics and Science Learning (pp. 33-48). Washington, DC: American Educational Research Association.

Cakici, Y., \& Bayir, E. (2012). Developing children's views of the nature of science through role play. International Journal of Science Education, 34(7), 1075-1091. https:/ / doi.org/10.1080/09500693.2011.647109

Catsambis, S. (1995). Gender, race, ethnicity, and science education in the middle grades. Journal of Research in Science Teaching, 32(3), 243-257. https:// doi.org/10.1002/tea.3660320305

Ceylan, E., Polat, R. K., Akpınar, M., Ulusal, E., \& Kalender, S. (2015). Designing science instruction based on creative drama: The effect on 6th grade students' understanding and elimination of misconceptions. International Online Journal of Educational Sciences, 7(4), 1-10. https:/ / doi.org/10.15345/iojes.2015.04.001

Choi, Y., Yang, J., H. \& Hong, SH. (2016). The effects of smart media based STEAM program of 'Chicken Life Cycle' on academic achievement, scientific process skills and affective domain of elementary school students. Journal of Korean Elementary Science Education, 35(2), 166-180. https:/ / doi.org/10.15267/ keses.2016.35.2.166

Çokadar, H., \& Yılmaz, G. C. (2010). Teaching ecosystems and matter cycles with creative drama activities. Journal of Science Education and Technology, 19(1), 80-89. https:/ / doi.org/10.1007/s10956-009-9181-3

Colucci-Gray, L., Burnard, P., Cooke, C., Davies, R., Gray, D. S., \& Trowsdale, J. (2017). BERA Research Commission Reviewing the potential and challenges of developing STEAM education through creative pedagogies for 21st learning: how can school curricula be broadened towards a more responsive, dynamic, and inclusive form of education? British Educational Research Association. Retrieved from https://www.researchgate.net/publication/319213173_ BERA_Research_Commission_Reviewing_the_potential_and_challenges_of_developing_STEAM_educati on_through_creative_pedagogies_for_21st_learning_how_can_school_curricula_be_broadened_towards_a _more_respons/download

Crouch, C. H., Wisittanawat, P., \& Renninger, K. A. (2013). Initial interest, goals, and changes in CLASS scores in introductory physics for life sciences. In P. Engelhardt (ed.), Proceedings of the Physics Education Research Conference (pp. 105-108). Melville, NY: AIP.

DeBacker, T., \& Nelson, R. (2000). Motivation to learn science: Differences related to gender, class type, and ability. The Journal of Educational Research, 93(4), 245-254. https:/ / doi.org/10.1080/00220670009598713

Deloitte Access Economics. (2014). Australia's STEM workforce: A survey of employers. Office of the Chief Scientist, Australian Government.

Dogru, M., Yilmaz, T. T., Kalay, A., \& Gençosman, T. (2010). Effect of creative drama method in science and technology course on the attitudes of primary school fifth grade students towards the course and on their achievements. Practice and Theory in Systems of Education, 5(2), 133-144.

Durik, A. M., \& Harackiewicz, J. M. (2007). Different strokes for different folks: How individual interest moderates the effects of situational factors on task interest. Journal of Educational Psychology, 99, 597-610. https:/ / doi.org/10.1037/0022-0663.99.3.597

Fabrigar, L. R., Petty, R. E., Smith, S. M., \& Crites, S. L. (2006). Understanding knowledge effects on attitudebehavior consistency: The role of relevance, complexity, and amount of knowledge. Journal of Personality and Social Psychology, 90(4), 556-577. https:/ / doi.org/10.1037/0022-3514.90.4.556

Fraser, B. J. (1981). Test of Science-Related Attitudes: Handbook. Victoria: Australian Council for Educational Research.

French, D. P., \& Russell, C. P. (2001). A statistical examination of student achievement and attitude in a large enrolment inquiry-based, introductory, biology course. Paper presented at the 2001 Conference of the National Association for Research in Science Teaching. St. Louis, Missouri.

Gardner, P. L. (1975). Attitudes to science. Studies in Science Education, 2(1), 1-41. 
Glasson, G. (1993). Reinterpreting the learning cycle from a social constructivist perspective: A qualitative study of teachers' beliefs and practices. Journal of Research in Science Teaching, 30(2), 187-207. https://doi.org/10.1002/tea.3660300206

Glynn, S. M., Brickman, P., Armstrong, N., \& Taasoobshirazi, G. (2011). Science motivation questionnaire II: Validation with science majors and nonscience majors. Journal of Research in Science Teaching, 48(10), 11591176. https:/ / doi.org/10.1002/tea.20442

Gul, E., \& Gucum, E. B. (2015). Creative drama applications as complementary for constructivist approaches for science courses: Teacher and student's evaluations. Procedia-Social and Behavioral Sciences, 174, 2043-2050. https:/ / doi.org/10.1016/j.sbspro.2015.01.875

Hardiman, M., Magsamen, S., McKhann, G., \& Eilber, J. (2009). Neuroeducation: Learning, arts, and the brain. New York, NY: Dana Press.

Hendrix, R. C. (2011). Using creative dramatics to foster conceptual learning in a science enrichment program (Ph.D. dissertation), Auburn University, Auburn, Alabama.

Hendrix, R., Eick, C., \& Shannon, D. (2012). The integration of creative drama in an inquiry-based elementary program: The effect on student attitude and conceptual learning. Journal of Science Teacher Education, 23(7), 823-846. https:/ / doi.org/10.1007/s10972-012-9292-1

Hidi, S. (2006). Interest: A unique motivational variable. Educational Research Review, 1(2), 69-82.

Hidi, S., \& Renninger, K. (2006). The four-phase model of interest development. Educational Psychologist, 41(2), 111127. https://doi.org/10.1207/s15326985ep4102_4

Holmegaard, H. T., Madsen, L. M., \& Ulriksen, L. (2012). To choose or not to choose science: Constructions of desirable identities among young people considering a STEM higher education programme. International Journal of Science Education, 36(2), 186-215. https:/ / doi.org/10.1080/09500693.2012.749362

Hung, C.M., Hwang, G. J., \& Huang, I. (2012). A project-based digital storytelling approach for improving students' learning motivation, problem-solving competence and learning achievement. Educational Technology $\mathcal{E}$ Society, 15(4), 368-379.

Jarvis, T., \& Pell, A. (2005). The relationships between primary teachers' attitudes and cognition during a two year science in-service programme. In K. Boersma, M. Goedhart, O. D. Jong, \& H. Eijkelhof (Eds.), Research and the quality of science education, (pp. 157-168). Netherland, Springer.

Katz, Y. J. (2002). Attitudes affecting college students' preferences for distance learning. Journal of Computer Assisted Learning, 18(1), 2-9. https://doi.org/10.1046/j.0266-4909.2001.00202.x

Kim, E., Kim, S., Nam, D., \& Lee, T. (2012). Development of STEAM program Math centered for middle school students. Retrieved from http://www.steamedu.com/wpcontent/uploads/2014/12/Development-of-STEAMKorea-middle-school-math.pdf

Kim, S., Jiang, Y., \& Song, J. (2015). The effect of interest and utility on Mathematics engagement and achievement. In K. A. Renninger, M. Nieswandt, and S. Hidi (eds), Interest in Mathematics and science learning (pp. 63-78). Washington, DC: American Educational Research Association.

Kivunja, C. (2015). Exploring the pedagogical meaning and implications of the 4Cs "Super Skills" for the 21st century through Bruner's 5E lenses of knowledge construction to improve pedagogies of the new learning paradigm. Creative Education, 6(2), 224-239. https:/ / doi.org/10.4236/ce.2015.62021

Kong, Y. T, Huh, S. C., \& Hwang, H. J. (2014). The effect of theme-based STEAM activity programs on self-efficacy, scientific attitude, and interest in scientific learning. International Information Institute (Tokyo). Information, 17(10), 5153-5159.

Krapp, A. (1999). Interest, motivation and learning: An educational-psychological perspective. European Journal of Psychology of Education, 14(1), 23-40.

Lave, J., \& Wenger, E. (1991). Situated learning: Legitimate peripheral participation. Cambridge, England: Cambridge University Press. https:/ / doi.org/10.1017/CBO9780511815355

Lehtonen, A., Kaasinen, M., Karjalainen-Väkevä, M., \& Toivanen, T. (2016). Promoting creativity in teaching drama. Procedia - Social and Behavioral Sciences, 217, 558-566. https:/ / doi.org/10.1016/j.sbspro.2016.02.046

Lent, R. W., Brown, S. D., \& Hackett, G. (1994). Toward a unifying social cognitive theory of career and academic interest, choice and performance. Journal of Vocational Behavior, 45(1), 79-122. https:/ / doi.org/10.1006/jvbe.1994.1027

Liao, C., Motter, J. L., \& Patton, R. M. (2016). Tech-savvy girls: Learning 21st-century skills through STEAM digital artmaking. Art Education, 69(4), 29-35. https://doi.org/10.1080/00043125.2016.1176492 
Low, K. S. D., Yoon, M., Roberts, B. W., \& Rounds, J. (2005). The stability of vocational interests from early adolescence to middle adulthood: A quantitative review of longitudinal studies. Psychological Bulletin, 131(5), 713-737. https:/ / doi.org/10.1037/0033-2909.131.5.713

Maltese, A. V., \& Tai, R. H. (2010). Eyeballs in the fridge: Sources of early interest in science. International Journal of Science Education, 32(5), 669-685. https:/ / doi.org/10.1080/09500690902792385

McCaslin, N. (2006). Creative drama in the classroom and beyond (8 $8^{\text {th }}$ ed.). Boston, MA: Allyn \& Bacon.

Mji, A., \& Makgato, M. (2006). Factors associated with high school learners' poor performance: a spotlight on mathematics and physical science. South African Journal of Education, 26(2), 253-266.

Naithram, R. (2014). How music education powers the STEAM movement. neaToday. Retrieved from http:/ / neatoday.org/2014/07/16/how-music-education-powers-thesteammovement

Nye, C. D., Su, R., Rounds, J., \& Drasgow, F. (2012). Vocational interests and performance: A quantitative summary of over 60 years of research. Perspectives on Psychological Science, 7(4), 384-403. https:/ / doi.org/10.1177/174569161244902

Osborne, J., Simon, S., \& Collins, S. (2003). Attitudes towards science: A review of the literature and its implications. International Journal of Science Education, 25(9), 1049-1079. https:/ / doi.org/10.1080/0950069032000032199

Özbek, G. (2014). Drama in education: Key conceptual features. Journal of Contemporary Educational Studies / Sodobna Pedagogika, 65(1), 46-61.

Ozdemir, P., \& Ustundag, T. (2007). Creative education program related to famous scientists in the field of science and technology. Primary Education Online Magazine, 226-233.

Ozek, M. B. (2016). The effect of creative drama on student achievement in the course of information technologies. Journal of Education and Training Studies, 4(6), 51-57. https:/ / doi.org/10.11114/jets.v4i6.1370

Peter, M. (2003). Drama, narrative an early learning. British Journal of Special Education, 30 (1), 21-27. https://doi.org/10.1111/1467-8527.00277

Reeve, J., \& Jang, H. (2006). What teachers say and do to support students' autonomy during a learning activity. Journal of Educational Psychology, 98(1), 209-218. https:/ / doi.org/10.1037/0022-0663.98.1.209

Renninger, K. A. (2000). Individual interest and its implications for understanding intrinsic motivation. In C. Sansone \& J. M. Harackiewicz (Eds.), Intrinsic and extrinsic motivation: The search for optimal motivation and performance (pp. 373-404). San Diego, CA: Academic Press.

Renninger, K. A., \& Hidi, S. (2016). The power of interest for motivation and engagement. New York, NY: Routledge.

Rotgans, J. I. (2015). Validation study of a general subject-matter interest measure: The Individual Interest Questionnaire (IIQ). Health Professions Education, 1(1), 67-75. https:/ / doi.org/10.1016/j.hpe.2015.11.009

Rotgans, J. I., \& Schmidt, H. G. (2011). Situational interest and academic achievement in the active-learning classroom. Learning and Instruction, 21(1), 58-67. https:/ / doi.org/10.1016/j.learninstruc.2009.11.001

Rounds, J., \& Su, R. (2014). The nature and power of interests. Current Directions in Psychological Science, 23(2), 98103. https:// doi.org/10.1177/0963721414522812

Ryan, R. M., \& Deci, E. L. (2000). Self-determination theory and facilitation of intrinsic motivation, social development and well-being. American Psychologist, 55(1), 68-78.

Salta, K., \& Tzougraki, C. (2004). Attitudes toward chemistry among 11th grade students in high schools in Greece. Science Education, 88(4), 535-547. https:/ / doi.org/10.1002/sce.10134

Sansone, C., \& Thoman, D. B. (2005). Interest as the missing motivator in self-regulation. European Psychologist, 10(3), 175-186. https:/ / doi.org/10.1027/1016-9040.10.3.175

Schmidt, K. M., \& Kelter, P. (2017). Science fairs: A qualitative study of their impact on student science inquiry learning and attitudes toward STEM. Science Educator, 25(2), 126-132.

Schwab, K. (2016). The fourth industrial revolution. Switzerland, World Economic Forum.

Şengun, Y., \& Iskenderoglua, T. (2010). A review of creative drama studies in math education: aim, data collection, data analyses, sample and conclusions of studies. Procedia - Social and Behavioral Sciences, 9, 1214-1219. https:/ / doi.org/10.1016/j.sbspro.2010.12.309

Senko, C., \& Harackiewicz, J. M. (2002). Performance goals: The moderating roles of context and achievement orientation. Journal of Experimental Social Psychology, 38(6), 603-610. https://doi.org/10.1016/S00221031(02)00503-6

Shadish, W. R., Cook, T. D., \& Campbell, D. T. (2002). Experimental and quasi-experimental designs for generalized causal inference. Boston, MA: Houghton Mifflin. 
Shams, L., \& Seitz, A. R. (2008). Benefits of multisensory learning. Trends in Cognitive Sciences, 12(11), 411-417. https://doi.org/10.1016/j.tics.2008.07.006

Silvia, P. (2008). Appraisal components and emotion traits: Examining the appraisal basis of trait curiosity. Cognition E Emotion, 22(1), 94-113. https:/ / doi.org/10.1080/02699930701298481

Sousa, D. A., \& Pilecki, T. (2013). From STEAM to STEAM: Using brain-compatible strategies to integrate the arts. Thousand Oaks, CA: Corwin.

$\mathrm{Su}, \mathrm{R}$. (2012). The power of vocational interests and interest congruence in predicting career success (Unpublished doctoral dissertation). University of Illinois at Urbana-Champaign.

Sun, H., Chen, A., Ennis, C., Martin, R., \& Shen, B. (2008). An examination of the multidimensionality of situational interest in elementary school physical education. Research Quarterly for Exercise and Sport, 79(1), 62-70. https:/ / doi.org/10.1080/02701367.2008.10599461

Sungurtekin, Ş., Sezer, G. O., Kahraman, P. B., \& Sadioğlu, Ö. (2009). The views of pre-service teachers about creative drama: A study according to gender. Elementary Education Online, 8(3), 755-770.

Swackjamer, L. E., Koellner, K., Basile, C. \& Kimbrough D. (2009). Increasing the self-efficacy of inservice teachers through content knowledge. Teacher Education Quarterly, 36(2), 63-78.

Taskin-Can, B. (2013). The effects of using creative drama in science education on students' achievements and scientific process skills. Elementary Education Online, 12(1), 120-131.

Taylor, P. C. (2016, August). Why is a STEAM curriculum perspective crucial to the 21st century? In ACER Research Conferences 2016. Retrieved from https:/ / research.acer.edu.au/research_conference/RC2016/9august/6

Timothy, J., \& Apata F. S. (2014). Effects of creative drama - based instruction on basic science achievement and scientific attitudes in Lagos State. ATBU, Journal of Science, Technology E Education (JOSTE), 2(2), 59-65.

Trowsdale, J. (2015). Psycho-physical theatre practice as embodied learning for young people with learning disabilities. International Journal of Inclusive Education, 19(10), 1022-1036. https:/ / doi.org/10.1080/13603116.2015.1031832

Vygotsky, L. S. (1978). Mind in society: The development of higher psychological processes. Cambridge, MA: Harvard University Press.

Weinburgh, M. (1995). Gender differences in student attitudes toward science: A meta-analysis of the literature from 1970 to 1991. Journal of Research in Science Teaching, 32(4), 387-398. https://doi.org/10.1002/tea.3660320407

Wienk, M. (2017). Some students are enrolled in more than one mathematics subjects. Discipline Profile of the Mathematical Sciences 2017, AMSI (University of Melbourne), Melbourne.

Yager, R. E. (1996). History of Science/Technology/Society as reform in the United States. In R. E. Yager (Ed.), Science/Technology/Society as a reform in science education (pp. 3-15). New York: State University of New York. 


\section{APPENDIX}

\section{Guidelines for Creative Drama Preparation}

Create and design a creative drama based on the theme that your group received. However, other themes (apart from the theme that you received) may be included into the creative drama. The creative drama should last for about 15 minutes.

1. Select and focus on an idea/topic: Discuss with your group members to choose, focus, and decide on the ideas/topic(s).

2. Create the story outline and plot: For a story to be good, there should be conflicts to generate tension and drive the development of characters and plot. An interesting story will have a few plot twists. A great twist will surprise the audience.

3. Identify the situation and time for your story: Where and when does the story take place? In how many locations/scenes will the story occur? Visualize the situations/scenes and stories that could happen.

4. Identify the characters/roles: You may have only one character in your creative drama. However, it will be more interesting if there are multiple characters (protagonist and antagonists) interacting in the creative drama. Decide the role, characteristics and the background of each characters. Identify the relationships among the characters.

5. Write dialogue: Write a brief monologue for each of your characters followed by some dialogue between two or more characters and etc.

6. Practice your creative drama: Discuss with your group members each time after the practice. During the discussion, try to answer these questions: Is the story clear? Are the characters/roles clear? What works? What was good? What can be changed to make it better? Improvise the creative drama while you are practicing it. Do not be afraid in rewrite, remove and rearrange the story plot and scenes.

7. Prepare the scenes, props and costumes: Prepare the scenes, props and costumes by using all available facilities and be creative.

\section{http://www.ejmste.com}

